\title{
MANAGING THE ANTHROPOCENE: RELATIONAL AGENCY AND POWER TO RESPECT PLANETARY BOUNDARIES
}

\author{
Pasi Heikkurinen ${ }^{1,2}$, Stewart Clegg ${ }^{3}$, Ashly H. Pinnington ${ }^{4}$, \\ Katerina Nicolopoulou ${ }^{5}$, Jose M. Alcaraz ${ }^{6}$
}

\begin{abstract}
This article examines how agency should be conceptualized to manage the pressing problems of the Anthropocene in support of sustainable change. The article reviews and analyzes literature on agency in relation to planetary boundaries, advancing the relational view of agency in which no actors are granted a primary ontological status and agency is not limited to humans but may be attributed to other actors. This understanding of agency can effectively contribute to sustainable organizations; on the one hand, it enables non-anthropocentrism and on the other hand, admits that networks bind actors. We conclude that boundary blurring (between actors) and boundary formation (between actors and networks) are complementary processes. Consequently, relationality is proposed as an applicable means of respecting planetary boundaries, while recognizing that all action flows through circuits of power whose obligatory passage points are the major conduits for intervention. Intervention occurs through regulation and nudging action such as ecotaxation.
\end{abstract}


${ }^{1}$ University of Helsinki, Finland; ${ }^{2}$ University of Leeds, UK; ${ }^{3}$ University of Technology Sydney, Australia; ${ }^{4}$ The British University in Dubai, United Arab Emirates; ${ }^{5}$ University of Strathclyde, UK; ${ }^{6}$ Munchen Business School 


\section{INTRODUCTION}

The concept of the Anthropocene is now well established in both mainstream natural and social sciences (Biermann, Bai, Bondre, Broadgate, Chen, Dube, Erisman, Glaser, van der Hel, Lemos, Seitzinger and Seto, 2016; Hamilton, Bonneuil, and Gemenne, 2015; Latour, 2015). In 2000, Nobel Laureate Paul Crutzen and Eugene F. Stoermer proposed that the impact of human beings' organized activities on Earth is so significant that the current geological epoch can be called the Anthropocene: the age of humans (Crutzen and Stoermer, 2000). The challenges of the humaninduced global environmental change have been extensively debated for decades (e.g., Carson, 1962; Meadows et al., 1972; Georgescu-Roegen, 1975) but the scale of human agency on Earth systems and related processes are now more evident and quantifiable (Andonova and Mitchell, 2010; Liu et al., 2015). The concept of the Anthropocene universalizes social, material, ecological and geological realities into one common environment: planet Earth. While the notion of the Anthropocene may be typical of totalizing narratives (see Lyotard, 1979; Parker, 1995), it plays the significant discursive role of promoting global awareness and collective responsibility for unfolding multi-scalar ecological crises. In addition, the notion spurs reflection on contemporary axiologies, ontologies, and epistemologies (Cunha et al., 2008; Hoffman and Jennings, 2015; Heikkurinen et al., 2016). Latour (2014a), for example, argues for consideration of the so-called metamorphic zone in which natural and material forces amalgamate and act, including Earth itself. From this perspective, all forms of agency inhabit a flat ontology in which human actors and the networks of activities in which they are engaged have no a priori theoretical privilege as actors per se (Pickering, 1995; Latour, 1999a and 1999b; Collinge, 2006; Latour, 2009).

The Anthropocene begins with modern industrialization, the Great Acceleration (Crutzen and Stoermer, 2000; Hamilton, 2015). In the early stages of the Anthropocene, human agency was largely unbounded in its effects on the fabric of the Earth and human life upon it, as Engels' (1892) remarkable chronicle of 1844 reveals. Organizations that sprung up in the industrial and capitalist revolution were framing the planet's fabric in new ways as they created new materialities. Many of these materialities were the effects of untrammeled organizational action, as the widespread degradation that Engels observed, bears testament: dark satanic mills in which bouts of daily exploitation occurred had as their retreats dank slums in which 
the majority of inhabitants were housed and whatever they earned in exchange value as rent further exploited. Exploitation was careless of all forms of life as it framed and constructed new social realities premised on a world of indifference to industrially induced disease, detritus, decay, dire pollution and, as scientists became aware late in the Anthropocene, disturbing changes in climatic conditions. ${ }^{1}$

For most organizations, most of the time, climate change has been just another externality (e.g. Marechal and Lazaric, 2010; Banerjee, 2012). The results of contestation concerning responsibility for these externalities among different organizations, such as political parties, lobby organizations, transnational corporations (TNCs) and media, has seen slow improvement, in some places, of some aspects of life on Earth. Major cities, such as London, no longer suffer the killer smog of the 1950s, since the domestic use of coal was phased out. However, externalities travel; as Beck (2009), has noted, we inhabit a global risk society. Environmental degradation and pollution produced in one place does not stay there but mingles with the air, water and soil of the planet. In consequence, the 'safe operating space for humanity' (Rockström et al., 2009; see also Barnosky et al., 2012; Steffen et al, 2015) and other forms of life diminishes both here and now and temporally: the future perfect becomes less and less an imaginary utopia (Bauman, 2017).

Whilst the Anthropocene enfolds all forms of life, there are evident power asymmetries not only amongst these different forms of being but also between different regions, groups, and social classes of humans, the dominant form of life (Moore, 2014; Malm and Hornborg, 2014). It is not humanity as a whole that is responsible for these externalities that threaten life itself but those central to the circuits of power characterizing human life, argue contemporary prominent

\footnotetext{
${ }^{1}$ Although relatively early in the process one prominent social scientist saw the dependence of this new form of industrial capitalist form of life on the exploitation of nature: Weber (2013, p. 182-3) concluded his investigations of the spirit of capitalism with the observation that the Puritan ethos, on which capitalism's primitive accumulation was founded, "“wanted to work in a calling; we are forced to do so.' For when asceticism was carried out of monastic cells into everyday life, and began to dominate worldly morality, it did its part in building the tremendous cosmos of the modern economic order. This order is now bound to the technical and economic conditions of machine production which today determine the lives of all the individuals who are born into this mechanism, not only those directly concerned with economic acquisition, with irresistible force. Perhaps it will so determine them until the last ton of fossilized coal is burnt."
} 
feminists (cf. Gibson-Graham, 2011; Haraway, 2015). Moreover, the global command of wealth and other organizational resources in organizational and actor networks straddling the globe inscribe some powerful actors with much more in the way of strategic choices over the vast range of organisms, materialities and imaginaries within which all life thrives and dies (Anderson and Cavanagh, 1996; Vitali et al., 2011; Malm and Hornborg, 2014; Ulvila and Wilén, 2017)².

The aim of the present article is to outline an understanding of agency with which contemporary managers might organize their activities in relation to ecological limits. The first section positions research on the Anthropocene before reviewing agency in its light. Possible management responses that could delay, if not prevent, further extinctions are considered and policies that could serve as nudges of managerial and organizational action are proposed, centering on an example of ecotaxation.

\section{AGENCY}

Agency is not only an attribute of being human. Agency, according to Latour, is fundamentally relational and based on processes of becoming through actor-network relationships (Latour, 1990) in which dynamic forms of agency are inscribed. Latour (2014a, p. 17) suggests that: '.. far from trying to "reconcile" or "combine" nature and society, the task, the crucial political task, is on the contrary to distribute agency as far and in as differentiated way as possible — until, that is, we have thoroughly lost any relation between those two concepts of object and subject ...' The principle of irreducibility of agency means 'nothing is inherently either reducible or irreducible to anything else' (Harman, 2007, p. 33). As agencies continuously engage, with, mobilize and translate materialities and imaginaries in and out of life's processes, networks of 'human or non-human entities, individual or collective, [are becoming]

\footnotetext{
${ }^{2}$ These actor-network relations have been traced across disciplinary fields from politics and discourse theories (Luukkonen, 1997; Venturini, 2010) to managing organizational change (Ezzamel, 1994; Lee and Hassard, 1999; Blomme, 2014), learning (Fox, 2000), routines (Bapuji, 2012), responsibility (Helin and Babri, 2015), work (Houtbeckers and Taipale, 2017) and the environment (Magnani, 2012; Ogden et al., 2013). Critical reviews of the idea of actor-network relations have appeared in the work of McLean and Hassard (2004) Alvesson et al. (2008) Whittle and Spicer (2008) and Alcadipani and Hassard (2010), amongst others.
} 
defined by their roles, their identity, and their program' (Latour, 1997, p. 55). 'As long as they act, agents have meaning' (Latour, 2014a, p. 14).

Social science studies of agency have tended to over-emphasize the role of human actors (Fleetwood, 2005; Orlikowski, 2010). While not reifying the products of human action, one consequence is that anthropocentric worldviews -favouring human agency at the expense of the non-human world - became institutionalized (Heikkurinen et al., 2016). The limitations of anthropocentrism in dealing with ecological problems have been reported over several decades (Purser et al., 1995; Gladwin et al., 1995; McShane, 2007; Ezzamel and Willmott, 2014; Bonnedahl and Heikkurinen, 2019). For example, the human-non-human divide makes taking the “'intermediary' and ambivalent status of animals in a growing number of organizational situations' problematic, note Doré and Michalon (2016, p. 15). An anthropocentric understanding of agency does not 'draw a definitive boundary between the objects (them) and us' (Introna, 2009, p. 31). Hence, solving the complex ecological problems that organizations now face (see also Purser et al., 1995; Boons, 2013; Heikkurinen et al., 2016; Connolly and Cullen, 2017) requires research that moves beyond anthropocentrism. One way of doing so is to take the Anthropocene seriously as a context both for theorizing and for practice.

Since the 1990s, an increasingly influential group of management scholars have expressed concerns about the roles and responsibilities of business organizations in advancing environmental sustainability. The Academy of Management established an active Organizations and Natural Environment Interest Group in 1991, but the general consensus arising from members' published work from the outset has been that positive change was occurring far too slowly. For example, within the context of greening organizations, Shrivastava and Hart (1992) noted that despite the rise of environmentalism during the 1970s and 1980s, the majority of organizations were failing to address the major issues. Shrivastava (1995a) criticized traditional approaches to management for their outmoded assumptions based on processes of industrialization during the 20th and 19th centuries, claiming that within numerous industries managers were biased towards patterns of production and consumption motivated by financial risk. The fundamental epistemology and ontology informing most management systems, Shrivastava argued, was anthropocentric with managers promulgating a 'denatured view' of the organizational environment. Deveraux Jennings and Zandbergen (1995) advocated applying concepts from institutional 
theory to understand how consensus is achieved on the meaning of sustainability and how sustainability practices are developed and diffused in programs for total quality environmental management, life-cycle analysis, product stewardship, ecoefficiency, pollution prevention and waste-management strategy, environmental risk and liability management, environmental banking and investment. Application of concepts from institutional theory continue over 20 years later to be influential in academic debates on the natural environment serving as an informative means of explaining societal and organizational change (e.g., Hoffman and Jennings, 2018; Maguire and Hardy, 2009; York, Hargrave and Pachecho, 2016). Shrivastava (1995b) argued that corporations actually have the financial resources, technological knowledge and institutional capacity for achieving ecological sustainability, albeit sharing responsibility along with governments and consumers. 'Nature must be valued for its own sake [...]' (p. 957), he asserted, claiming corporations could make an immediate difference through total quality environmental management and by implementing ecologically sustainable competitive strategies.

In recent reflexive understandings, distributed networks of diverse entities and complex localized assemblages constituting the Anthropocene produce critical zones and potential tipping points of ecological destruction (Barnosky et al., 2012; Steffen et al., 2015; Hoffman and Jennings, 2018). Humans have the power to exercise reflexivity towards all other agencies as a result of the communicative competence afforded by various forms of natural and technical language game (Wittgenstein, 2009) in their constitution of what Giddens' (1984) terms both practical, as in ordinary language, as well as theoretical consciousness, as in the elaborated codes of scientific and related fields of practice. Understanding how human agency relates to the agency of non-human actors becomes a critical competence (Carolan, 2005; Ivakhiv, 2002). It is only through the reflexive capacities which predicate the human actor that the interests of those non-human agencies that have material effects can be represented.

Sociologically, humans and non-humans are inextricably implicated in acts of agency in which humanity's reflexive capabilities, by developing new scientific, social and ethical approaches to living in the world, can work towards the collective good. Being is 'inevitably endowed with a moral and political history' (Latour, 2014b, p. 4), one that is earthbound, inescapably tied to this Earth. The Earth's agential role is to support the standing conditions that enable life on Earth. Humans' 
reflexive capacity in grasping how climate interacts with humans in sustaining or threatening forms of life is increasingly channeled through technical discourses of climate science and intellectual discoveries based on detailed research investigations made within multiple disciplines increasingly (Latour, 2014c). Assembled into new sets of actions, these insights and creative ideas have the potential to lead to the development of novel competences and more responsible agency.

\section{BOUNDARIES AND BOUNDEDNESS}

Contemporary reflexive capacities in the sciences are increasingly oriented to the planetary boundary $(\mathrm{PB})$ framework as the relevant context for interpreting the Anthropocene (Rockström et al., 2009; Steffen et al., 2015). The PB framework encompasses nine Earth system thresholds, the standing conditions for life on Earth, the consequences of crossing which are potentially catastrophic. The PB framework directs academic and practitioner attention not merely to climate change (the topic currently attracting the most attention) but also to other Earth systems relevant to sustainable change: the rate of biodiversity loss (terrestrial and marine); interference with the nitrogen and phosphorus cycles (e.g. from the nitrogen used in fertilizers); stratospheric ozone depletion; ocean acidification; global freshwater use; change in land use; chemical pollution, and atmospheric aerosol loading (see e.g. Hoffman and Jennings, 2018). Embracing radical ecological relationality, identifying global hotspots, acknowledging interactions far beyond the knowledge of any singular discipline, the PB model sees the role of scientific knowledge in the preservation of the planet as a pragmatic and legitimate process requiring urgent action (Van den Bergh and Kallis, 2012; Whiteman et al., 2013).

The PB framework is shedding new light on 'the problem of scale' (Perey, 2014, p. 215), providing insights into how to address connections between the different systems or hierarchical scales that constitute the planetary system (Boulding, 1966). The boundaries of these are framed by strategic devices that bind and divide, through acts of defining, separating, assimilating; that stabilize, through acts of fixing, delimiting, controlling and that make visible, through acts of empirical recognition through technologies of representation and control (after Campbell, McHugh and Eennis, 2018). In this way, boundaries are constituted that stretch from 'ocean 
basins/biomes or sources/sinks to the level of the Earth system as a whole' (Steffen et al., 2015, p. 2). Steffen et al. (2015) observe that at least four system boundaries (rate of biodiversity loss, climate change, human interference with the nitrogen cycle, and land-system change) appear to have already been transgressed in ways that cannot be repaired or will be extremely challenging to reverse (see also Rockström, Richardson, Steffen and Mace, 2018). These, in common with the other PBs, entail practices connecting individuals, organizations, societies and global networks.

The science behind the PBs findings is a set of resources for reflexive thinking and application of expert knowledge. The PB framework affords a relational and hierarchical understanding of the world's systems (Heikkurinen et al., 2015; Hoffman and Jennings, 2018) that is limited in its reproduction of an exclusively anthropocentric view in which the agency of non-human stakeholders is recognized only insofar as it offers a more or less safe operating space for humans and other forms of life (cf. Waddock, 2011).

Natural science-related questions are readily raised, such as how much freshwater from rivers, lakes, reservoirs and renewable groundwater stores can and should be withdrawn before it constitutes a trespass over the global freshwater threshold (Rockström and Karlberg, 2010; Steffen et al., 2015). We can seek to calibrate the precise contribution of international trade and certain industries, such as tea, sugar, textiles and fish consumption, to the loss of biodiversity (Lenzen et al., 2012). Comparatively, we can question which agricultural regions contribute most to the biogeochemical flow (phosphorus) boundary and how can agriculture can be reorganized (globally) so that the land-use boundary is not crossed (Foley et al., 2011).

These questions are not only a concern for natural science but also for social science: indeed, they are organizational in question. Organizations' impact on Earth systems (e.g. ocean acidification, ozone layer depletion, and climate change) and on subglobal processes, such as land and water use is well known as are the consequences of environmental degradation for human organization (Steffen and Smith, 2013; Steffen et al., 2015). Transgression of the PBs is evidence of the failure of industrial and of post-industrial societies to recognize the Anthropocene. A group of scholars in business concerned about organizations and the natural environment argue that the last few decades reveal blatant disconnection between problem recognition and 
positive response (Gladwin, 1995, 2012; Hoffman and Jennings, 2013, p. 24-5). The boundary framework seeks to embed reflexive human actors in an ecological network that is ultimately a planetary process (e.g. Waddock, 2011; Heikkurinen et al., 2015). Moreover, process implies politics (Orssatto and Clegg, 1999; Hoffman and Jennings, 2018); for instance, processes of ecological destruction cause severe problems for earthbound actors the risks associated with which are not equally distributed spatially or in terms of social stratification both globally and nationally.

Conventionally, time is represented in sequential process as 'flows from past to present' (Latour, 2004, p. 11). Analytically, we are aware that time's arrow bends both back and forth; through reflexive capacities humans (at least) reassemble the past from the here and now and project the future backwards by thinking in the future perfect, as Schutz (1967) explained. Human actors have a tendency to reflect on their future plans and predictions as if they are events that have already happened. While the phenomenological instantiation of the future perfect might seem inconsequential, the scale can be changed as we build realistic scenarios of probable futures, as Pitsis, Clegg, Rura-Polley and Marozeky (2003) investigated empirically.

Different human agencies are capable of different projections, which vary with what Jacques (1971) termed the time span of discretion, the length of the longest task an individual can successfully undertake and take responsibility for, a concept he addressed intra-organizationally in terms of human intelligence and capabilities. Building on the initial idea and transforming it into one capable of more global application, we can refer to the projective reach of strategic decision-making. Organizationally, the most senior incumbents of high office with strategic responsibilities have the greatest time span of discretion and thus the greatest projective reach into the future.

Temporal capacities provide an in-principle flat ontology in which various actors are capable of different projective reach. At the outer temporal limits, we have the projective reach of a Chernobyl or a Fukushima nuclear meltdown that renders zones of life critical into all foreseeable futures for those actors that occupy them. Nuclear reactors can be powerful autonomous actants (Ellul [1954] 1973, Vadén, 2014). It is a matter of strategy, politics and ethics on the part of human actors whether these non-human actors' powers are unleashed on Earth. In terms of a nuclear plant, the temporal horizon is effectively infinite in terms of generational lifespans. One way 
of capturing the inequality of being is through the notion of projective reach. While all actants exist together in the horizontal and vertical 'web of life' (Capra, 1995; Waddock, 2011), they do not exist equally in temporal terms: the projective reach of a nuclear plant far exceeds that of a mosquito, for instance. The mosquito might give one a bite; the bite might produce inflammation at best; at worse it might produce a debilitating virus in a human subject. Should that subject, in a fever, have recourse to fly a plane or drive an automobile, the impact of that small insect might be far greater than one initially might envisage. The mosquito, for all intents and purposes, however, does not aim to cause harm. It has no language game that translates to humans and in which the idea of harm would make sense; instinctually, it merely seeks preferential food. It is the intentional effects of humans' causal powers and their interactions with the causal powers of other actors that are of concern to us as social scientists seeking an organizational response to the Anthropocene.

Pragmatically, if we combine the horizontally-broad understanding of flat ontology that recognizes the powers of all earthbound actors with a conception of the projective reach of organizational decision-making, strategic managers would become more heedful of the interaction between humans and those other powers that potentially broach PBs. Acknowledgement of the power of all actors and their interactions necessitates more enlightened scientific information gathering, decision-making and practices with respect to an audit of the future perfect impact of actions planned to be undertaken on a diverse range of interests. After all, as Collinge (2006, p. 244) notes, it is by:

$[\mathrm{P}]$ rojecting a world that is divided not only into a 'horizontal' structure (in which similar activities are organized at similar scales in different places) but also a 'vertical' structure (in which different activities are organized at different scales covering the same places), that scale analysis acquires its conceptual power.

There are appropriate management responses to being in the multi-scalar Anthropocene society (Hoffman and Jennings, 2018); for instance, the processes of organizing might become conceived as flat and hierarchical endeavors linking those near to those distant, us to them, we to others, while maintaining pragmatic network boundaries necessary for respecting the uniqueness of all actors and their powers. In other words, apposite management of the Anthropocene would be characterized by 
an understanding of agency that builds on two key dimensions. The first one is the horizontal dimension that Latourian flat ontology offers and the other is the vertical dimension from ecology, where all earthbound action is embedded in the biosphere. In terms of flat ontology, flatness is first and foremost the refusal to treat one strata of reality as predominant and superior to all others. As Latour (1988) states, nothing is, by itself, either reducible or irreducible to anything else. ${ }^{3}$

Albeit abstract, the conceptual merging of equally existent but distinctively intentional causal powers furthers the vital integration of natural and social sciences in exploring the management of business organizations. The point of the PBs is that crossing their thresholds triggers causal powers that will be extremely difficult to reverse once unleashed. Boundary claims, whether planetary or otherwise (see Latour, [1991] 2012), as well as claims of boundary absence, have effects that are real in their consequences. It is for this reason that politico-ethical reflection and audit, as well as regulatory institutions, become important: what boundaries of future perfect projection are being audited and regulated by organizations for which managers are held responsible and what boundaries remain non-issues in organizations' strategy?

The matter of these boundaries flows down from global initiatives such as the Paris climate accord, through state regulation requiring specific forms of audit, through to initiatives undertaken on the basis of organizational volition. Ideally, at each level of the nine Earth systems identified, systematic audit should be conducted in terms of the construction of a future perfect scenario in which minimization of harm is the purpose to be achieved, cascading through the levels to the organizational and framing of the individual. The causal powers of strategic management intersect with the casual powers of two kinds of matter: first, that which matters, because it is accounted for, audited and regulated; second, that which does not matter in terms of the intentional agency of any specific strategy as it is not accounted for, audited, or regulated. All matter might potentially be extinguished if not managed, relinquishing its casual powers, including species, as well as other forms of life. Importantly, however, organizations' strategic choices can hasten or hinder processes of extinction and the conditions of being. Matter matters, mainly because

\footnotetext{
${ }^{3}$ That this is the case does not preclude the irreducible difference between a concept and an object. Language games, signifiers, signs, and sensations exist in conjunction with human actors and non-humans.
} 
dematerialization is a utopia (see Foster, 2012), but it does not matter with the same immediacy as does a language game in which one's business is inscribed, irrespective of will, an inscription that enacts an economic calculation of profit and loss that is tightly temporally constrained.

As a response to the Anthropocene, Hoffman and Jennings (2018) propose, informed by Perrow (2011), that there is a need for institutional entrepreneurship, social movements and policy shifts. Theory and practice could be enlightened by more sophisticated ideas of resilience, modularity and decoupled institutions. Cultural perspectives suffuse proactive social commitments. Managers fostering 'stakeholder cultures' can shift the cultural axis from amoral, egoist or instrumentalist cultures to constituting cultures preferentially concerned with the welfare and rights of planetary sub-systems as stakeholders (Jones et al., 2007, p. 138). Due to the nonanthropocentric understanding of agency, such cultures can be highly inclusive. Sophisticated ideas of procedural and distributive justice inform ethical corporate perceptions of fairness and increased contribution to social welfare (Bosse and Phillips, 2016). Ethical human resource management approaches in regard to the treatment of people are also informed by similar ideas (Bergstrom and Diedrich, 2011; Pinnington, Macklin and Campbell, 2007). Adopted by CEOs and boards of directors as a core aspect of strategic management these approaches could inform actions concerned with the wellbeing of non-human stakeholders of the nine subsystems.

The multidimensional view, accompanied by temporal analysis, opens up new avenues for thinking about stakeholder salience (Bundy et al., 2013) in terms of questions of power and legitimacy (Mitchell et al., 1997). These questions are deeply cultural: think of the changing treatment of human beings historically. Their instrumental use as slaves is no longer regarded as legitimate nor is the power of bondage any longer a culturally acceptable form of power. Managers always manage in complex circuits of power that are culturally constituted, institutionalized and legitimated. Increasingly, practitioners' legitimacy flows from being beholden in an equitable relation with non-human actors embedded within those ecological limits that bound action; responsibility is becoming culturally enlarged.

Episodically, for responsible management in contemporary times the precautionary principle needs to be paramount in relation to all stakeholder agencies, in addition to 
human agents, in various ecological systems. Dispositionally, in terms of social integration, new sets of rules and meanings in terms of audit accountabilities need to be routinized. Facilitatively, in terms of system integration, the conception of relevant network systems needs expanding from a focus simply on socio-technic, human and organizational systems to embrace the nine planetary sub-systems identified. If multidimensionality is included in the question of agency, we will see that the biosphere, as well as social systems, sets normative limits to agency: what can and should be done (see Waddock, 2011). The planetary level boundaries are examples of the kind of limits that should not be transgressed, of causal powers that should not be triggered, of standing conditions that should not be created.

The outlined perspective is likely also to lead to sensitivity towards the needs of nonhuman actors, as all actors will be considered to hold agential capacities in an interconnected web of life. Interestingly, blurring the boundaries between actors in the web can be considered a key means to acknowledging and respecting the relations between actors and their networks, i.e. between the parts and the wholes. Furthermore, by cultivating multidimensional understanding, managers will develop broader ethical concerns as they begin to conceive themselves as actors amidst other earthbound beings, rather than as a privileged and dominant form of life. In consequence, organizational decision-making that does not privilege egotistical, human-centric approaches will understand human agency as something enmeshed with non-human actors, in addition to other fellow humans and organizations.

To understand human agency as something enmeshed with non-human actors, in addition to other fellow humans and organizations, language games must change; being in the language game and the being in the flat ontology of the Anthropocene require reconciliation. The reconciliation cannot be one wholly of social construction; if that were the case, climate sceptics would have as much validity as climate scientists, despite the latters' grounded, modelled and empirical understanding of materialities' casual powers. Without a changed understanding of agency, powerful organizations are likely to continue resisting the accountabilities and controls of environmental laws and regulatory conditions that seek to keep them within the PBs.

The complexity of the Anthropocene requires more holistic modes of thinking about management (Waddock, 2011; Hoffman and Ehrenfeld, 2014; Hoffman and 
Jennings, 2018). Theorizing management to meet the challenges of the new geological epoch requires consideration of aspects of both nature and culture. In addition, materialities such as 'partnerships, materials use and supply chains, domains of corporate activity, organizations' as well as the 'economic models and the metrics that are used to measure them' (Hoffman and Ehrenfeld, 2014, p. 2), need rethinking. New language games are required because both the materialities and the language games matter. The boundaries of actor networks require collective attention and consequently new language games deploying standards, ideas, tools and approaches that constitute less destructive collaborations across multilevel networks and assemblages.

\section{ACTION}

In organization theory, for sustainable development to be more than an oxymoron, as Banerjee (2003) argues, organizations of different sizes, forms, and ownership types must share responsibility for restraining action within the boundaries of safe operating spaces. Of course, as Campbell et al. (2018) assert, these boundaries may already be irretrievably breached, in which case pessimism of the intellect must retain hope in the optimism of the will (Gramsci, 1971) in order to learn how organizational forms may operate, while contributing to sustainable change, as we shall suggest.

Despite the volume of growing published evidence, the majority of contemporary business organizations and institutions have demonstrated that they are not prepared to take the idea of material boundaries into consideration. Admittedly, the task of connecting causalities on multiple scales is a challenge not limited to the business sector. Institutional legislative and regulatory measures need rethinking (see e.g. Hoffman and Jennings, 2018): as Giddens (2008) argues, the state has a prime function in tackling climate change, especially in terms of negotiating international treaties and enforcing them, advocating the creation of the 'ensuring state' as an enabling state that is "expected or obligated to make sure ... processes achieve certain defined outcomes - in the case of climate change the bottom line is meeting set targets for emissions reductions" (Giddens, 2008, pp. 8-9). It is important, however, not to fall prey to naivety. Capitalism is still capitalism and without social 
democratic limits to its principle of freedom to consume we may well witness the sixth mass extinctions (see Cabellos, Ehrlich, Barnosky, García, Pringle and Palmer, 2015).

The Anthropocene 'forms an indeterminate but insidious threshold at which many actions previously normal or insignificant have become, often in all innocence, themselves destructive, simply by virtue of human numbers and power' (Clark, 2015 , p. 61). The power of human numbers can be a force for good, however. Human numbers can nudge organizations to better organizational actions but this is unlikely to be achieved without the support of the state regulatory mechanisms. Often, strategic decision makers are not fully aware of the cumulative effects of their everyday praxis and hence many remain unpersuaded of the pressing need for change in management style and organization vision (Tourish and Pinnington, 2002). From the perspective of the Anthropocene the bottom line to which managers attend needs to encompass at least all nine sub-systems in addition to concerns over profit and people.

Awareness of the 'Anthropocene Society' (Hoffman and Jennings, 2018), often fostered in civil society through the learning that children bring home from school, can make a difference, eroding the pessimism of those intellects arguing against a realignment of causal powers: sustainable change may then be more evident. Business actors in TNCs have the collective resources, capabilities and potential power to project knowledge about the Anthropocene through all their endeavors as well as the agency to reduce the rate and extent of ecological damage. Maak and Pless (2009, p. 544), for instance, have highlighted the new role of 'business leaders as citizens of the world'. Such citizens assume a disposition focused on the 'distant stranger' (Dobson, 2006, p. 182), characterized by 'cosmopolitanism' (Delanty, 2006, p. 44). ${ }^{4}$

In their longitudinal case study research, Wright and Nyberg (2017) note though the failure of corporate environmentalism to galvanize Australian firms into a cosmopolitan, collective reduction of global carbon emissions. They point to the incompatibility of stockholder accountabilities and short-term business pressures

\footnotetext{
${ }^{4}$ It is noteworthy that these are the very terms in which a recent significant retreat from cosmopolitanism has been conducted: Brexit; see Alcaraz, Sugars, Nicolopoulou, and Tirado (2016) for relevant discussion of 'cosmopolitanism or globalization'.
} 
with a care for sustainability of the environment in the long-term. Nevertheless, according to Winn and Pogutz (2013), there is recent evidence of an increasing number of corporate initiatives deliberately managing ecosystem functions and monitoring biological diversity and ecosystem services, although practice in this area is well ahead of management research. Related arguments of practice being ahead of theory can be found in some of the research on cross-sectoral partnerships established to implement innovative solutions to deal with the aftermath of events causing environmental crisis (Doh, Taschman and Benischke, 2017).

On the positive side, much of the research work in business management is becoming more responsive to diverse scientific, political, commercial and community challenges of sustainability and offers many concrete proposals advancing sustainable practice in management and organization. New frameworks are being published to assist corporations and their managers with engaging in deliberative and global governance for responsible innovation (Voegtlin and Scherer, 2017). Business and management theories are now more accustomed than they were thirty years ago to accommodating concepts of social and environmental responsibility.

Institutional theory, strategic management, entrepreneurship, system dynamics, network analysis, supply chain management and social movements are just some of the areas of business and management theory that have examined issues related to the natural environment, although within these disciplines concepts of natural resources remain markedly less prevalent than do other financial, social and intangible concepts of organizational resources and environments (George, Schillebeeckx and Link, 2015). Within 'Anthropocene Society' a prima facie justification arises for scholars of organization, management and business to enrich their theoretical, conceptual representations of the natural environment. Hoffman and Jennings (2015, p. 9) remark that the distinctive contribution of much institutional theory is it 'emphasizes environmental problems as being not primarily technological or economic in character but behavioral and cultural'. In addition to institutional entrepreneurship and social movements, regulative measures on corporate actors and networks are also needed for sustainable change, as proposed by Hoffman and Jennings (2018). Owing to the power of commercial actors, the enactment of these reforms requires multi-level collaboration beyond sectorial boundaries (Bonnedahl and Heikkurinen, 2019). In business and government decision-making, it is often the natural environment that loses out to finance and 
economics in the competition for resources (Nyberg, Wright and Kirk, 2017); thus, its increased theoretical status and representation in the social sciences, especially those of applied business, is therefore a critical issue for theory and practice.

Currently, there is both abundant information as well as management tools that are available for reducing the use of natural resources and climate emissions (e.g., Lenzen et al., 2012) but management thinking and action has not demonstrated the required will to overcome the cultural constraints across their networks of activities. The language games of temporally short term and tight profitability prevail over those of irreducible causal powers vested in materialities. Effective action in response to the challenges of the PBs requires not only highly collaborative and insightful ways of enacting responsible agency (rather than merely publishing attractive reports on corporate sustainability) but also political will and direction, a strong public sector and an ensuring state (nationally and internationally), although there are no guarantees that knowledge about how to manage a business in the Anthropocene will lead to responsible action.

That actor networks are tightly interconnected affords reason for optimism of the will. Business leaders are astutely aware of the power of their cooperation since '.. nearly $4 / 10$ of the control over the economic value of TNCs in the world is held, via a complicated web of ownership relations, by a group of 147 TNCs in the core, which has almost full control over itself' (Vitali et al., 2011, p. 36). They appreciate that often 'strength arises [exactly] when an entity manages to assemble as many allies as possible, while weakness emerges when it is isolated or cut off from alliances' (Harman, 2007, p. 33). In close connection with state actors, the elite group of global business organizations has successfully strengthened their agency and power across the scales. While some individual members of this group are taking sustainability action with the support of, for example, multiregional input-output models (Lenzen et al., 2012), these perform inadequately as a network in relation to the Anthropocene. Establishing an effective management response to the Anthropocene requires a collective effort, through which business actors gain momentum by assembling alliances whose agency demands changes in the industry and supports democratic mechanisms to ignite change at large (Heikkurinen and Mäkinen, 2018). While acknowledging the limits of state-oriented solutionism (e.g. Scott, 1998), there must be limits to capital and it seems that only the state could ensure them. 


\section{RESPONSIBILITY}

Responsibility necessitates pursuit of future perfect conditions that explicitly demonstrate care directed towards multiple stakeholders, including ecosystems. Approaches analogous to ANT, we propose, are supportive of increasing transdisciplinary thought and education, an area that Latour repeatedly emphasizes. Based on ideas of networks and assemblages, ANT offers principles for reflexive thinking and responsible action consonant with multistakeholder partnerships incorporating the needs of ecosystems. Diverse global and local community collaborations constituted on broad and representative participation will have to be instigated and nurtured by powerful elite groups in politics and business. Many of the cross-sectoral partnerships and voluntary initiatives in soft regulation and inclusion have been characterized to-date by immediate rather than elaborated interests.

Latour (2014b, p. 6) asserts, "the "anthropos" of the Anthropocene is not exactly any body, it is made of highly localized networks of some individual bodies whose responsibility is staggering.' It is important to ascribe responsibility for the Anthropocene 'to whom and where it belongs' (Latour, 2014, p. 7). There are Common But Differentiated Responsibilities in the Anthropocene (cf. Latour, 2009). Despite existing in webs of relations, actors (whether human or not) are never fully defined by their relationships with others (Harman, 2002, 2009; Pierides and Woodman, 2012) but embody different kinds and degrees of agency (Heikkurinen et al., 2016; Heikkurinen, 2018), with consequently different responsibilities. Latour's work on the Anthropocene offers a variety of intellectual and cultural approaches potentially incorporating ecological modes of perception and reasoning.

Owing to anthropogenic ecological damage humans have a distinct responsibility in the Anthropocene. Non-humans, such as organizations with fictive legal personality, might well ignite changes in the biosphere as a result of their agency but it will take human initiative in the first instance. The multidimensional perspective on agency prepares a new role for humans to be more responsible and ecologically sound (Bennett, 2010). To assign responsibility solely to corporate networks is risky, even though their potential power to make a difference is great. Political action (Heikkurinen, Lozanoska and Tosi, 2018) and activism (Niazi, 2018), as well as grassroots innovations (Seyfang and Smith, 2007), can supply the initiative. 
Evidently, action by multinationals can be channeled positively or negatively. In terms of the Anthropocene there are 'obligatory passage points' (OPPs) (Callon, 1986) that represent strategic devices (rhetorical and material) channeling and framing the 'conduct of conduct' (Dean, 2013). Actors seek to maintain, gain or deny strategic advantage by controlling or contesting the meaning and control of these OPPs. How these OPPs are configured also fixes, for a while, the rules guiding actors' actions and constraining available possibilities. When successful, OPPs lead to a (temporary and partial) stabilization or fixity of rules, though one that is permanently challengeable as actors continuously deploy their strategies of and for power. The OPPs can be configured while the materialities are more difficult: their casual powers are ontologically inherent but the standing conditions through which they are triggered are not: these are a matter of social construction. Where and how actions flow is largely dependent on those language games in which they are embedded and framed. Power always entails responsibility, as Lukes (1974) makes clear.

In Clegg's (1989) framework of 'circuits of power' depicting three circuits of flows these responsibilities are variously assigned. First, the episodic circuit captures visible exercises of power by actors in particular, day-to-day encounters, seeking to obtain outcomes favoring their definition of interests, for which they are responsible. These exercises depend on the configuration of the network of relations stabilized through the other two circuits. The circuit of social integration captures prevailing rules of practice shaping actors' dispositions to behave in certain ways and includes rules of meaning and membership defining taken-for-granted responsibilities: these are encapsulated in specific language games whose rules guide actors in making sense of the world, events, others and themselves, hence shaping the actors' knowledge which, in turn, underlies their (re)actions. Considerations about actors' appropriate action, in the context of identity assumptions and claims, given their (actual or desired) status as members of certain groups, follow. 'Material conditions', based on the application of techniques of production and discipline to materialities, through production machinery, information systems, organizational structures and business processes, convey power as facilitative, productive, positive, in the circuit of system integration, assigning material, social and knowledge responsibilities. Together, language games and their techniques of production and discipline positioned as OPPs frame the institutional field in which actors episodically exercise power in specific interactions, as Hoffman and Jennings (2015) acknowledge. In a 
nutshell, organizations need strategically to first reposition the language games they are involved in because these offer the primary point of inflection in terms of addressing the thresholds of the causal powers inscribed in the PBs. For organization to contribute to sustainable change, it must play its part in these new language games implementing collaborations across assemblages of multilevel social and physical networks supporting human development that are consonant with flourishing ecosystems. Managing in the Anthropocene demands openness to a wider set of resources for reflexive thinking. Ensuring the sustainability of future generations on Earth places greater onus on business leaders because it obliges them to demonstrate higher standards of politico-ethical reflection and action than hitherto.

One example of repositioning can be seen in Wiesner et al.'s (2017, p. 21) study of leaders of small and medium size companies who have reputation in their industries for environmental sustainability and commit to continuous learning and improvement, influencing others and becoming 'ES innovators'. Bennett notes that 'corporate regulation is one place where intentions might initiate a cascade of effects' and wonders whether, perhaps 'the ethical responsibility of an individual human now resides in one's response to the assemblages in which one finds oneself participating' (Bennett, 2010, pp. 37-38). Following this line of argumentation, it is not meaningful to discuss morality as separate from non-human objects or the 'material' world of technology (Ivakhiv, 2002; Latour, 2002). In circuits of power the technical and the moral are inseparable because together they constitute the OPPs (see Clegg, 1989).

While the blurring of boundaries between human and non-human actors must be acknowledged, this must not happen at the expense of losing those relations that make actors different. For example, it is commonly accepted that the reflexive qualities of intelligence expressed in a complex sign system of language and the exosomatic technological systems of humans are something that characterizes humankind. Consequently, only humans are able to project something like a future perfect. Empirical analyses of sustainable entrepreneurship have identified a group of cognitive, emotional and relational competences, under the rubric of strategic management, that promote diversity, systems thinking, normative, foresight and interpersonal relations (Ploum, Blok, Lans, Omta, 2018). These are reflexive qualities for future perfect construction. In short, human actors have the capacity to engage in innovative forms of socio-ecological agency (Boons, 2013). One need not 
rely on the voluntarism of individual acts of entrepreneurship, however; for capacities to become practicalities corporate networks require normative encouragement and this is where, for instance, the proposal for states' implementing ecotaxation becomes relevant, as a nudge that may be required.

The role of the state as an actor is crucial. The powers of the state include the monopoly of the right to taxation. The rate and principles of taxation are a piece of social construction in which various imaginaries can be encoded. As such, taxation changes become exogenous environmental contingencies with which organizations are obliged to deal. At present, some jurisdictions, including the United States and Australia, extend the right to tax profits globally. Taxing the foreign profits of TNCs on a global basis could be extended in a number of ways.

First, it could be recognized, as the French government has proposed, that companies lacking physical presence in a country in which they are accruing profits through large numbers of online users or customers should be taxed at the same rate as bricks and mortar businesses. If this proposal were adopted by various national governments then the beginnings of a global tax scheme would be in place. Such a scheme could be extended to include ecological taxation - ecotax - that could be levied as an excess and additional tax on those business actions whose activities anywhere in the world were breaching any of the nine PBs. The state is also the only actor that could establish caps on production either directly or through Pigouvian taxes, which Alcott (2010) sees as necessary to guarantee policy success for sustainable change. The Global Resources Dividend (GRD) proposed by Pogge (2001) might be a base model. Businesses would pay a tax on any services or resources that they use or sell rated proportionately to the harm that they create in extraction or production. Those business organizations that could establish that they had enacted policies that minimized the harm to the lowest rated harm decile of the tax register would pay a disproportionately lower tax than those businesses that could not so demonstrate that they qualified. Proportionality would vary with the demonstration of performance. Those organizational actors that could demonstrate commitment to circular economy principles would clearly be advantaged. Our line of argument is supportive of Landrum's (2017) stages model of sustainable development where the aim is to move away from weak sustainability typical of compliance and business-centered corporate approaches towards regenerative and 
co-evolutionary sustainability, where the emphasis is on absolute reductions of production and consumption activities (Bonnedahl and Heikkurinen, 2019).

The onus is on business organizations to demonstrate why they should not be taxed at the highest band. Tax will act as a nudge to the adoption of policies with transformative potential. Implementing some version of such an ecotax would entail not only discussions about practicality but also a normative affirmation of the power of projective reach. Again, the onus is on companies to demonstrate the precautionary principle in practice; those that fail to do so would be subject to highly discriminate taxes. If the majority of organizations were paying their GRD, the tax benefits of doing so would help deter deviance as self-interest drove responsible action. There would be added pressure on each country to enforce the gathering of GRD funds within its borders because of the tax advantages of so doing; the hosting of rogue businesses by non-compliant states could lead to these businesses being singled out for preferential and discriminatory tax treatment in the more developed states that implemented the ecotax principles.

\section{CONCLUSION}

In this article, we have examined how agency should be understood in order to overcome the persistent management challenges in the Anthropocene. We commenced by defining the Anthropocene not only as a geological epoch but also as a metamorphic zone in which boundaries between actors are increasingly blurred. We noted that this sets major challenges to the classic perspectives on agency; consequently, we drew on relational perspectives to meet the needs of the present age where planetary boundaries are being transgressed. Based on the observation that the boundaries between actors are increasingly unclear and that action is not predetermined, we chose to expand conceptions of agency beyond their normal locus of being situated only in humans.

A multidimensional understanding of agency that could support executives in managing their business networks through compliance with systematic audit and institutions in relation to ecological limits and hence contribute to sustainable change was proposed. In the horizontal dimension, a key means of respecting non-humans is to blur the boundaries between earthbound actors. Different forms of life unfold 
in a complex conjoint genesis with humans. In the vertical dimension, hierarchical relations are of central importance in defining boundaries between networks of actors in ecosystems. An analysis of the state of biodiversity would be impossible to conduct without some idea of boundaries between species as part of certain ecosystems. Boundary blurring (between actors) and boundary formation (between actors and networks) are complementary processes. Boundaries are not simply here and now; they are also temporal in that where the boundary is drawn today has potentially profound effects on the boundaries of tomorrow - the essence of the case for action against global warming. Establishing boundaries is of crucial importance in highlighting the uniqueness of actors and acknowledging responsibilities. To the extent that the boundary blurring between human and non-human actors signifies a retreat from anthropocentrism, the chances of life remaining within planetary boundaries increases. In other words, if the needs of non-human stakeholders are taken into account and met, the rate of biodiversity loss may begin to diminish and climate change slowed. Similar desired effects might be expected in terms of the other ecological boundaries.

Future studies on the Anthropocene and organizations could complement current ontological, epistemological and axiological premises with novel positions that do not center on the human but are more inclusive in terms of actors and networks. Theoretical lenses that extend beyond anthropocentrism and empirical analysis of human and non-human interaction (not limited to the human point of view) will be required. To ignite sustainable change, studies could identify the powerful actors in society and connect them to their responsibility for our common earthbound future. In practice the process of rethinking agency leads to greater consideration of the realms of actors and their interlinkages, implying greater attention on the part of those agencies with reflexive capabilities and command of key obligatory passage points in circuits of power, the TNCs (Clegg, Geppert and Hollinshead, 2018). Human agents, particularly managers in the most powerful TNCs, have distinct responsibility for the Anthropocene as a result of a concentration of circuits of power in their networks. Managers in TNCs can be motivated in terms of enlightened selfinterest; for instance, global trajectories of action can be nudged in more ecologically responsible directions through devices such as ecotaxation. 


\section{ACKNOWLEDGEMENTS}

This project has received funding from the European Union's Horizon 2020 research and innovation programme under the Marie Sklodowska-Curie grant agreement No 707652 .

\section{REFERENCES}

Alcadipani, R., \& Hassard, J. (2010). Actor-Network Theory, organizations and critique: Towards a politics of organizing. Organization, 17(4): 419-435.

Alcaraz, J. M., Sugars, K., Nicolopoulou, K., \& Tirado, F. (2016). Cosmopolitanism or globalization: The Anthropocene turn. Society and Business Review, 11(3): 313-332.

Alcott, B. (2010). Impact caps: Why population, affluence and technology strategies should be abandoned. Journal of Cleaner Production, 18(6): 552-560.

Alvesson, M., Hardy, C., \& Harley, B. (2008). Reflecting on reflexivity: Reflexive textual practices in organization and management theory. Journal of Management Studies, 45(3): 480-501.

Anderson, S. D., \& Cavanagh, J. (1996). The Top 200: The rise of global corporate power. Washington, DC: Institute for Policy Studies.

Andonova, L. B., \& Mitchell, R. B. (2010). The rescaling of global environmental politics. Annual Review of Environment and Resources, 35: 255-282.

Banerjee, S. B. (2003). Who sustains whose development? Sustainable development and the reinvention of nature. Organization Studies, 24(1), 143-180.

Banerjee, S. B. (2012). A climate for change? Critical reflections on the Durban United Nations climate change conference. Organization Studies, 33(12): 1761-1786.

Bapuji, H., Hora, M., \& Saeed, A. M. (2012). Intentions, intermediaries, and interaction: Examining the emergence of routines. Journal of Management Studies, 49(8): 1586-1607.

Barnosky, A.D., Hadly, E.A., Bascompte, J., Berlow, E.L., Brown, J.H., Fortelius, M., Getz, W.M., Harte, J., Hastings, A., Marquet, P.A., Martinez, N.D., Mooers, A., Roopnarine, P., Vermeij, G., Williams, J.W., Gillespie, R., 
Kitzes, J., Marshall, C., Matzke, N., Mindell, D.P., Revilla E., \& Smith, A.B. (2012). Approaching a State Shift in Earth's Biosphere. Nature, 486(7401): $52-58$.

Bauman, Z. (2017). Retrotopia. Cambridge: Polity.

Beck, U. (2009). World at risk. Cambridge, U.K.: Polity Press.

Bennett, J. (2010). Vibrant matter: A political ecology of things. Durham and London: Duke University Press.

Bergström, O., \& Diedrich, A. (2011). Exercising social responsibility in downsizing: enrolling and mobilizing actors at a Swedish high-tech company. Organization Studies, 32(7), 897-919.

Biermann, F., Bai, X., Bondre, N., Broadgate, W., Chen, C-T.A., Dube, O.P., Erisman, J.W., Glaser, M., van der Hel, S., Lemos, M.C., Seitzinger, S., \& Seto, K.C. (2016). Down to Earth: Contextualizing the Anthropocene. Global Environmental Change, 39: 341-350.

Blomme, R. J. (2014). Organisational change processes and emergence: Latourian, Weickean and Bourdieuian perspectives revisited. International Journal of Strategic Change Management, 5(4): 332-347.

Bonnedahl, K., \& Heikkurinen, P. (Eds.), (2019). Strongly sustainable societies: Organizing activities of a hot and full Earth. London: Routledge.

Boons, F. (2013). Organizing within dynamic ecosystems: Conceptualizing socioecological mechanisms. Organization \& Environment, 26(3): 281-297.

Bosse, D. A., \& Phillips, R. A. (2016). Agency theory and bounded self-interest. Academy of Management Review, 41(2): 276-297.

Boulding, K. E. (1966). The economics of the coming spaceship earth. In Jarrett, H (Ed.), Environmental Quality in a Growing Economy, Johns Hopkins University Press: London.

Bundy, J., Shropshire, C., \& Buchholtz, A. K. (2013). Strategic cognition and issue salience: Toward an explanation of firm responsiveness to stakeholder concerns. Academy of Management Review, 38(3): 352-376.

Ceballos, G., Ehrlich, P. R., Barnosky, A. D., García, A., Pringle, R. M., \& Palmer, T. M. (2015). Accelerated modern human-induced species losses: Entering the sixth mass extinction. Science Advances, 1(5): e1400253.

Callon, M. (1986). Some elements of a sociology of translation: domestication of the scallops and the fisherman of St Brieuc bay. In Law, J., (Ed.), Power, action and belief: a new sociology of knowledge, London: Routledge, 196-232. 
Campbell, N., McHugh, G., \& Ennis, P. J. (2018). Climate change is not a problem: Speculative realism at the end of organization. Organization Studies, 0170840618765553.

Capra, F. (1995). The web of life. New York: Anchor Doubleday.

Carolan, M.S. (2005). Society, biology, and ecology. Organization \& Environment, 18(4): 393-421.

Carson, R. (1962). Silent Spring. Boston, MA: Houghton Mifflin.

Clark, T. (2015). Ecocriticism on the edge: The Anthropocene as a threshold concept. London and New York: Bloomsbury Publishing.

Clegg, S. R. (1989). Frameworks of power. London: Sage.

Clegg, S., Geppert, M., \& Hollinshead, G. (2018). Politicization and political contests in and around contemporary multinational corporations: An introduction. Human Relations, 0018726718755880.

Collinge, C. (2006). Flat ontology and the deconstruction of scale: a response to Marston, Jones and Woodward. Transactions of the Institute of British Geographers, 31(2): 244-251.

Connolly, L., \& Cullen, J. (2017). Animals and organisations: An ethic of care framework. Organization \& Environment, doi.org/10.1177/1086026617712975.

Crutzen, P. J., \& Stoermer, E. F., (2000). 'The Anthropocene'. IGBP Newsletter 41, Royal Swedish Academy of Sciences, Stockholm.

Cunha, M. P.e., Rego, A., \& Vieira de Cunha, J. (2008). Ecocentric management: An update. Corporate Social Responsibility and Environmental Management, 15(6): 311-321.

Dean, M. (2013). The signature of power: Sovereignty, governmentality and biopolitics. London: Sage.

Delanty, G. (2006). The cosmopolitan imagination: Critical cosmopolitanism and social theory. The British Journal of Sociology, 57(1): 25-47.

Dobson, A (2006). Thick cosmopolitanism. Political Studies, 54: 165-184.

Doh, J.P., Tashman, P., \& Benischke, M. (2017). Adapting to grand environmental challenges through collective entrepreneurship. Academy of Management Perspectives, 7, https://doi.org/10.5465/amp.2017.0056Doré, A., \& Michalon, J. (2016). What makes human-animal relations 'organizational'? The De-scription of Anthrozootechnical Agencements, Organization, pp. 120, doi: 10.1177/1350508416670249. 
Ellul, J. ([1954] 1973). The technological society. Translated by Wilkinson, J., New York: Vintage Books.

Engels, F. (1892). The condition of the working class in England in 1844. London: Allen and Unwin.

Ezzamel, M. (1994). Organizational change and accounting: Understanding the budgeting system in its organizational context. Organization Studies, 15(2): 213-240.

Ezzamel, M., \& Willmott, H. (2014). Registering 'the ethical' in organization theory formation: Towards the disclosure of an invisible force. Organization Studies, 35(7): 1013-1039.

Fleetwood, S. (2005). 'Ontology in organization and management studies: A critical realist perspective', Organization, 12(2): 197-222.

Foley, J., Ramankutty, N., Brauman, K., Cassidy, E., Gerber, J., Johnston, M., Mueller, N., O'Connell, C., Ray, D., West, P., Balzer, C., Bennett, E., Carpenter, S, Hill, J., Monfreda, C., Polasky, S., Rockström, J., Sheehan, J., Siebert, S., Tilman, D., \& Zaks, D. (2011). Solutions for a cultivated planet. Nature, 478(7369): 337-342.

Foster, J. B. (2012). The planetary rift and the new human exemptionalism: A political-economic critique of ecological modernization theory. Organization \& Environment, 25(3): 211-237.

Fox, S. (2000). Communities of practice, Foucault and Actor-Network Theory. Journal of Management Studies, 37(6): 853-868.

George, G., Schillebeeckx, S.J.D., \& Liak, T.L. (2015). From the editors: The management of natural resources: an overview and research agenda. Academy of Management Journal, 58(6): 1595-1613.

Georgescu-Roegen, N. (1975). Energy and economic myths. Southern Economic Journal, 41(3): 347-381.

Gibson-Graham, J. K. (2011). A feminist project of belonging for the Anthropocene. Gender, Place and Culture, 18(1): 1-21.

Giddens, A. (1984). The constitution of society. Cambridge, UK: Polity Press.

Giddens, A. (2008). The politics of climate change: National responses to the challenge of global warming. Policy network paper. London: www.policynetwork.net. 
Gladwin, T. N., Kennelly, J. J., \& Krause, T. S. (1995). Shifting paradigms for sustainable development: Implications for management theory and research. Academy of Management Review, 20(4): 874-907.

Gladwin, T.D. (2012). Capitalism critique: Systemic limits on business harmony with nature. In P. Bansal \& A. Hoffman (Eds.), The Oxford handbook of business and the environment (pp. 657-674). Oxford, UK: Oxford University Press.

Gramsci, A., (1971). Selections from the prison notebooks of Antonio Gramsci, edited and translated by Hoare, Q., and Nowell, G. London, UK: Lawrence and Wishart.

Hamilton, C., Bonneuil, C., \& Gemenne, F. (2015). Thinking the Anthropocene. The Anthropocene and the global environmental crisis. New York: Routledge.

Hamilton, C. (2015). Getting the Anthropocene so wrong. The Anthropocene Review, 2(2): 102-107.

Haraway, D. (1991). Simians, cyborgs, and women. The Reinvention of nature. New York: Routledge.

Haraway, D. (2015). Anthropocene, Capitalocene, Plantationocene, Chthulucene: Making kin. Environmental Humanities, 6(1): 159-165.

Harman, G. (2002). Tool-being: Heidegger and the metaphysics of objects. Chicago, Il: Open Court Publishing.

Harman, G. (2007). The importance of Bruno Latour for philosophy. Cultural Studies Review, 13(1): 31-49.

Harman, G. (2009). Prince of networks: Bruno Latour and metaphysics. Prahran, Victoria: Re.press.

Heikkurinen, P. (2018). Degrowth by means of technology? A treatise for an ethos of releasement. Journal of Cleaner Production, 197: 1654-1665.

Heikkurinen, P. (Ed.), (2017). Sustainability and peaceful coexistence for the anthropocene. London and New York: Routledge.

Heikkurinen, P., \& Bonnedahl, K. J. (2013). Corporate responsibility for sustainable development: a review and conceptual comparison of market- and stakeholder-oriented strategies. Journal of Cleaner Production, 43: 191-198.

Heikkurinen, P., Lozanoska, J., \& Tosi, P. (2018). 'Activities of degrowth and political change', Journal of Cleaner Production, 211: 555-565. 
Heikkurinen, P., Rinkinen, J., Järvensivu, T., Wilén, K., \& Ruuska, T. (2016). Organising in the Anthropocene: An ontological outline for ecocentric theorising. Journal of Cleaner Production, 113: 705-714.

Heikkurinen, P., \& Mäkinen, J. (2018). Synthesising corporate responsibility on organisational and societal levels of analysis: An integrative perspective. Journal of Business Ethics, 149(3): 589-607.

Helin, S., \& Babri, M. (2015). Travelling with a code of ethics: A contextual study of a Swedish MNC auditing a Chinese supplier. Journal of Cleaner Production, 107: 41-53.

Hoffman A., \& Ehrenfeld, J. (2014). The fourth wave, management science and practice in the age of the Anthropocene. In E. Lawler, S. Mohrman, and J. O'Toole (Eds.), Corporate stewardship: Organizing for sustainable effectiveness. Sheffield, UK: Greenleaf.

Hoffman, A. J., \& Jennings, P. D. (2015). Institutional theory and the natural environment: Research in (and on) the Anthropocene. Organization \& Environment, 28(1): 8-31.

Hoffman, A., \& Jennings, P. D. (2018). Re-engaging with sustainability in the Anthropocene era: An institutional approach. Cambridge: Cambridge University Press.

Houtbeckers, E., \& Taipale, T. (2017). Conceptualising worker agency for the challenges of the Anthropocene: Examples from recycling work in the global north. In P. Heikkurinen (Ed.), Sustainability and Peaceful Coexistence for the Anthropocene. New York: Routledge.

Introna, L. D. (2009). Ethics and the speaking of things. Theory, Culture \& Society, 26(4), 25-46.

Ivakhiv, A. (2002). Toward a multicultural ecology. Organization \& Environment, 15(4): 389-409.

Jacques, E. (1971). Time-span handbook: The use of time-span of discretion to measure the level of work in employment roles and to arrange an equitable payment structure. London: Heinemann.

Jennings, P. D., \& Zandbergen, P. A. (1995). Ecologically sustainable organizations: An institutional approach. Academy of Management Review, 20(4): 10151052. 
Jones, T. M., Felps, W., \& Bigley, G. A. (2007). Ethical theory and stakeholderrelated decisions: The role of stakeholder culture. Academy of Management Review, 32(1): 137-155.

Landrum, (2017). Stages of corporate sustainability: Integrating the strong sustainability worldview. Organization \& Environment, doi.org/10.1177/1086026617717456

Latour, B. ([1991] 2012). We have never been modern. Boston, Massachusetts: Harvard University Press.

Latour, B. (1988). Irréductions, published with The Pasteurisation of France. Cambridge, MA: Harvard University Press.

Latour, B. (1990). Technology is society made durable. The Sociological Review, 38(S1): 103-131.

Latour, B. (1997). 'On recalling ANT', Keynote speech presented at 'Actor Network and After' Workshop at Keele University, England.

Latour, B. (1999a). Pandora's hope: Essays on the reality of science studies. Cambridge, MA: Harvard University Press.

Latour, B. (1999b). On recalling ANT. The Sociological Review, 47(S1): 15-25.

Latour, B. (2002). Morality and technology: The end of the means. Translation by Couze Venn. Theory, Culture \& Society, 19(5/6): 247-260.

Latour, B. (2009). Politics of Nature. Boston: Harvard University Press.

Latour, B. (2012). Waiting for Gaia. Composing the common world through arts and politics. Equilibri, 16(3): 515-538.

Latour, B. (2014a). Agency at the time of the Anthropocene. New Literary History, 45(1): $1-18$.

Latour, B. (2014b). 'Anthropology at the time of the Anthropocene - A personal view of what is to be studied', Distinguished Lecture, American Association of Anthropologists, Washington, December (draft for comments): 1-16.

Latour, B. (2014c). 'How better to register the agency of things', Tanner Lectures, Princeton: Yale University, $26^{\text {th }}-27^{\text {th }}$ March.

Latour, B. (2015). 'Telling friends from foes at the time of the Anthropocene', in C. Hamilton, C. Bonneuil, and F. Gemenne (Eds.), The Anthropocene and the Global Environment Crisis - Rethinking Modernity in a New Epoch, pp. 145155. London: Routledge, (originally given as a lecture, Thinking the Anthropocene, EHESS, Paris, 14 $14^{\text {th }}-15^{\text {th }}$ November, 2013. 
Lee, N., \& Hassard, J. (1999). Organization unbound: Actor-network theory, research strategy and institutional flexibility. Organization, 6(3), 391-404.

Lenzen, M., Moran, D., Kanemoto, K., Foran, B., Lobefaro, L., \& Geschke, A. (2012). International Trade Drives Biodiversity Threats in Developing Nations. Nature, 486(7401): 109-112.

Liu, J., Mooney, H., Hull, V., Davis, S. J., Gaskell, J., Hertel, T., ... Li, S. (2015). Systems integration for global sustainability. Science, 347(6225): 1258832.

Luukkonen, T. (1997). Why has Latour's theory of citations been ignored by the bibliometric community? Discussion of sociological interpretations of citation analysis. Scientometrics, 38(1): 27-37.

Lyotard, J-F. (1979). The postmodern condition: A report on knowledge. Manchester, UK: Manchester University Press.

Maak, T., \& Pless, N.M. (2009). Business leaders as citizens of the world: Advancing humanism on a global scale. Journal of Business Ethics, 88(3): $537-550$.

Magnani, N. (2012). Nonhuman actors, hybrid networks, and conflicts over municipal waste incinerators. Organization \& Environment, 25(2): 131-145.

Maguire, S., \& Hardy, C. (2009). Discourse and deinstitutionalization: the decline of DDT. Academy of Management Journal, 52(1): 148-178.

Malm, A., \& Hornborg, A. (2014). The geology of mankind? A critique of the Anthropocene narrative. The Anthropocene Review, 1(1): 62-69. 2053019613516291.

Marechal, K., \& Lazaric, N. (2010). Overcoming inertia: insights from evolutionary economics into improved energy and climate policies. Climate Policy, 10(1), 103-119.

McLean, C., \& Hassard, J. (2004). Symmetrical absence/symmetrical absurdity: Critical notes on the production of actor-network accounts. Journal of Management Studies, 41(3): 493-519.

McShane, K. (2007). Anthropocentrism vs. nonanthropocentrism: Why should we care? Environmental Values, 16(2): 169-185.

Meadows, D. H., Meadows, D. L., Randers, J., \& Behrens, W. W. (1972). The limits to growth. New York: Universe Books.

Mitchell, R. K., Agle, B. R., \& Wood, D. J. (1997). Toward a theory of stakeholder identification and salience: Defining the principle of who and what really counts. Academy of Management Review, 22(4): 853-886. 
Moore, J. W. (2014). The Capitalocene, Part I: On the nature \& origins of our ecological crisis. Working paper. Available from: http://www.jasonwmoore.com/uploads/The_Capitalocene_Part_I_June_20 14.pdf [Accessed 20th November 2015].

Niazi, T. (2018). 'Contesting instrumental knowledge with communicative action: Why Kalabagh dam (Pakistan) remains unbuilt. Organization \& Environment, 1086026618773696.

Nyberg, D., Wright, C., \& Kirk, J. (2017). Fracking the future: temporality, framing and the politics of unconventional fossil fuels. Academy of Management Proceedings, 1, https://doi.org/10.5465/ambpp.2017.104

Ogden, L., Heynen, N., Oslender, U., West, P., Kassam, K. A., \& Robbins, P. (2013). Global assemblages, resilience, and earth stewardship in the Anthropocene. Frontiers in Ecology and the Environment, 11(7): 341-347.

Orlikowski, W. J. (2010). The sociomateriality of organisational life: considering technology in management research. Cambridge Journal of Economics, (34): $125-141$.

Orssatto, R.J., \& Clegg, S.R. (1999). The political ecology of organizations: Toward a framework for analyzing business-environment relationships. Organization \& Environment, 12(3): 263-279.

Parker, M. (1995). Critique in the name of what? Postmodernism and critical approaches to organization. Organization Studies, 16(4): 553-564.

Perey, R. (2014). Organizing sustainability and the problem of scale: Local, global or fractal. Organization \& Environment, 27(3): 215-222.

Perrow, C. (2011). The next catastrophe: Reducing our vulnerabilities to natural, industrial, and terrorist disasters. Princeton, NJ: Princeton University Press.

Pickering, A. (1995). The mangle of practice: Time, agency and science. Chicago, IL: University of Chicago Press.

Pierides, D., \& Woodman, D. (2012). Object-oriented sociology and organizing in the face of emergency: Bruno Latour, Graham Harman and the material turn. The British Journal of Sociology, 63(4): 662-679.

Pinnington, A., Macklin, R., \& Campbell, T. (Eds.), (2007). Human resource management: Ethics and employment. Oxford, UK: Oxford University Press.

Pitsis, T., Clegg, S. R., Marosszeky, M., and Rura-Polley, T. (2003) 'Constructing the Olympic Dream: Managing Innovation through the Future Perfect', Organization Science, 14:5, 574-590. 
Ploum, L., Blok, V., Lans, T., \& Omta, O. (2018). Towards a validated competence framework for sustainable entrepreneurship. Organization \& Environment, 31(2): 113-132.

Pogge, T. W. (2001). Eradicating systemic poverty: Brief for a global resources dividend. Journal of Human Development, 2(1): 59-77.

Purser, R. E., Park, C., \& Montuori, A. (1995). Limits to anthropocentrism: Toward an ecocentric organization paradigm? Academy of Management Review, 20(4): 1053-1089.

Rockström, J., \& Karlberg, L., (2010). The quadruple squeeze: Defining the safe operating space for freshwater use to achieve a triply green revolution in the Anthropocene, Ambio, 39: 257-265.

Rockström, J., W. Steffen, K. Noone, A. Persson, F. S. Chapin, III, E. Lambin, T. M. Lenton, M. Scheffer, C. Folke, H. Schellnhuber, B. Nykvist, C. A. De Wit, T. Hughes, S. van der Leeuw, H. Rodhe, S. Sorlin, P. K. Snyder, R. Costanza, U. Svedin, M. Falkenmark, L. Karlberg, R. W. Corell, V. J. Fabry, J. Hansen, B. Walker, D. Liverman, K. Richardson, P. Crutzen, \& J. Foley. (2009). Planetary boundaries: Exploring the safe operating space for humanity. Ecology and Society, 14(2): 32.

Rockström, J., Richardson, K., Steffen, W., \& Mace, G. (2018). Planetary boundaries: separating fact from fiction. A response to Montoya et al. Trends in Ecology \& Evolution, 33(4): 233-234.

Schutz, A. ([1932]1967). The phenomenology of the social world. Evanston, IL: Northwestern University Press.

Scott, J. C. (1998). Seeing like a state: How certain schemes to improve the human condition have failed. New Haven: Yale University Press.

Seyfang, G., \& Smith, A. (2007). Grassroots innovations for sustainable development: Towards a new research and policy agenda. Environmental Politics, 16(4): 584-603.

Shrivastava, P. (1995a). Ecocentric management for a risk society. Academy of Management Review, 20(1): 118-137.

Shrivastava, P. (1995b). The role of corporations in achieving ecological sustainability. Academy of Management Review, 20(4): 936-960.

Shrivastava, P., \& Hart, S.L. (1992). Greening organizations. Academy of Management Proceedings, pp. 185-189. 
Steffen, W., \& Smith, M. (2013). Planetary boundaries, equity and global sustainability: Why wealthy countries could benefit from more equity. Current Opinion in Environmental Sustainability, 5: 403-408.

Steffen, W., Richardson, K., Rockström, J., Cornell, S.E., Fetzer, I., Bennett, E.M., Biggs, R., Carpenter, S.R., de Vries, W., de Wit, C.A., Folke, C., Gerten, D., Heinke, J., Mace, G.M., Persson, L.M., Ramanathan, V., Reyers, B., \& Sörlin, S. (2015). Planetary boundaries: Guiding human development on a changing planet. Science, 347: 6223.

Tourish, D. J., \& Pinnington, A. H. (2002). Transformational leadership, corporate cultism and the spirituality paradigm: An unholy trinity in the workplace? Human Relations, 55(2): 147-172.

Ulvila, M., \& Wilén, K. (2017). 'Engaging with the Plutocene: Moving towards degrowth and post-capitalistic futures', In P. Heikkurinen (Ed.), Sustainability and peaceful coexistence for the Anthropocene. London and New York: Routledge.

Vadén, T. (2014). Next nature and the curse of oil. Next Nature. Available at: https://www.nextnature.net/2014/02/next-nature-and-the-curse-of-oil/

Van den Bergh, J. C., \& Kallis, G. (2012). Growth, A-growth or Degrowth to stay within planetary boundaries? Journal of Economic Issues, 46(4): 909-920.

Venturini, T. (2010). 'Diving in magma: How to explore controversies with ActorNetwork Theory', Public Understanding of Science, 19(3): 258-273.

Vitali, S., Glattfelder, J. B., \& Battiston, S. (2011). The network of global corporate control. PLoS ONE, 6(10): e25995.

Voegtlin, C., \& Scherer, G.A. (2017). Responsible innovation and the innovation of responsibility: governing sustainable development in a globalized world. Journal of Business Ethics, 143(2): 227-243.

Waddock, S. (2011). We are all stakeholders of Gaia: A normative perspective on stakeholder thinking. Organization \& Environment 24(2): 192-212.

Weber, M. (2013). The Protestant ethic and the spirit of capitalism. Routledge.

Weisner, R., Chadee, D., \& Best, P. (2017). Managing change toward environmental sustainability: A conceptual model in small and medium enterprises. Organization \& Environment, 31(2): 152-177.

Whiteman, G., Walker, B., \& Perego, P. (2013). Planetary boundaries: Ecological foundations for corporate sustainability', Journal of Management Studies, 50(2): 307-336. 
Whittle, A., \& Spicer, A. (2008). Is Actor Network Theory critique? Organization Studies, 29(4): 611-629.

Winn, M.I., \& Pogutz, S. (2013). Business, ecosystems, and biodiversity: new horizons for management research. Organization \& Environment, 26(2): 203229.

Wittgenstein, L. (2009). Philosophical investigations. London: John Wiley \& Sons.

Wright, C., \& Nyberg, D. (2015). Climate change, capitalism and corporations: Processes of creative self-destruction. Cambridge: Cambridge University Press.

Wright, C., \& Nyberg, D. (2017). An inconvenient truth: How organizations translate climate change into business as usual. Academy of Management Journal, 60(5): 1633-1661.

York, J.G., Hargrave, T.J., \& Pacheco, D.F. (2016). Converging winds: logic hybridization in Colorado wind energy field. Academy of Management Journal, 59(2): 579-610. 